
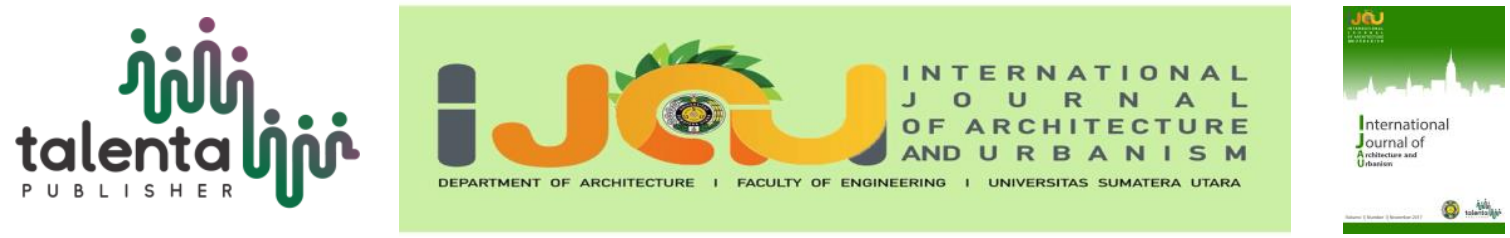

\title{
The Use of Metaphor in Designing Dance Academy
}

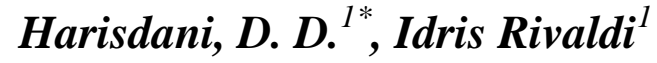 \\ ${ }^{1}$ Architecture Departement, Faculty of Engineering, Universitas Sumatra Utara, Medan, Indonesia
}

\begin{abstract}
In the context that a formal education in dance art is needed in Medan, Indonesia, therefore research about establishing dance academy needs to be done. Focusing on the problem that lies in the pride of the dancers, Metaphor appears as a solution in creating a Dance Academy in which the dancers can take pride of. By collecting data directly from the site or literature review, the appropriate way of using the metaphor is determined and interpreted into the building, thus creating an Architecture model that has a very strong bond with the dance art as a whole.
\end{abstract}

Keywords: academy, architecture, dance art, metaphor

\section{Introduction}

Dance Art was a hobby that was often made as a medium for self-actualization in teenage society. Thus in the context that a dance academy is needed to provide formal education for the teenagers, one of the problems that need to be solved is the pride of the dancers has for their academy.

As dancers who have the soul of art, it is certain that they hoped that their academy to be unique and artistic. Artistic buildings can be created through a unique visualization of the buildings. The meaning of the visualization here is the mass, form, and the façade of the building, which can be seen through the eyes. These artistic forms, mass and façade design, can be created through the use of metaphor. Aside from enabling more expressive design for building visualization, the use of metaphor can also bring the bond of relevancy between the dance academy and dance art itself [1].

\footnotetext{
*Corresponding author at : Department of Architecture, Faculty of Engineering, Universitas Sumatera Utara, Jalan Perpustakaan Gedung J07,Medan 20155,Indonesia

E-mail address : devin.defriza@usu.ac.id
} 


\section{Literature Review}

Function and Architectural Design

Dance or Tari in Indonesian is the movement of the body (hands, etc.), which have rhythm, usually follows by sounds (music, etc.) [2]. Academy is a high education institution ( \pm three years long) which educates professional workforce like military and art [2].

A metaphor is a way to compare two things or more, which has no relation from one to another. A metaphor opens a new perspective on their observer in understanding something [3]. The meaning of metaphor in architecture is a simile that is expressed in the form of buildings with the hope that others might catch the essence and the meaning from the building form.

There are three categories of metaphors in architecture. (a)Intangible metaphors, (untouchable metaphors) is a metaphor which uses essences, concept, ideas, and values like individualism, naturalism, communication, tradition, and culture into the form of the building (b)Tangible metaphors (real metaphors that can be seen), a metaphor that uses visuals, specification, character, from an object which is used in the process of forming the building mass (c) Combined metaphors, is a combination of the first and the second category which compare the visual of an object as well as the similarity in the concept, idea and their value into the building [4].

Generally, metaphors can be considered as a tool in the process of forming the building mass. However, one thing which needs to be noted is that the use of metaphor is not simply limited to mass forming only. Aside from the exterior form of the buildings, form as a whole, including the quality of the interior room and space, can also be designed using metaphors.

\section{Concept}

To achieve an efficient and effective design, it is best to form the guidance of the rooms and spaces requirement. The room requirement guidance is made from a direct analysis of the existing academy and also data from a book. The primary needs of high educational facilities are an auditorium, administration room, head director room, sports center, canteen, dormitory, and parking area [5]. Data of the activity flow and the room requirements of the dance academy is also needed. Those data are analyzed and are used to create a reference that takes form as a room program table to create effective and efficient spaces.

The concept of mass-forming is done by choosing a basic form that is given subtraction or addition of elements (Figure 1) to obtain a similar visual form to the dancers, which are used in the metaphor. Depend on how we subtract or add the mass element, the identity of the form itself could be changed or preserved as how we wanted to [6]. 


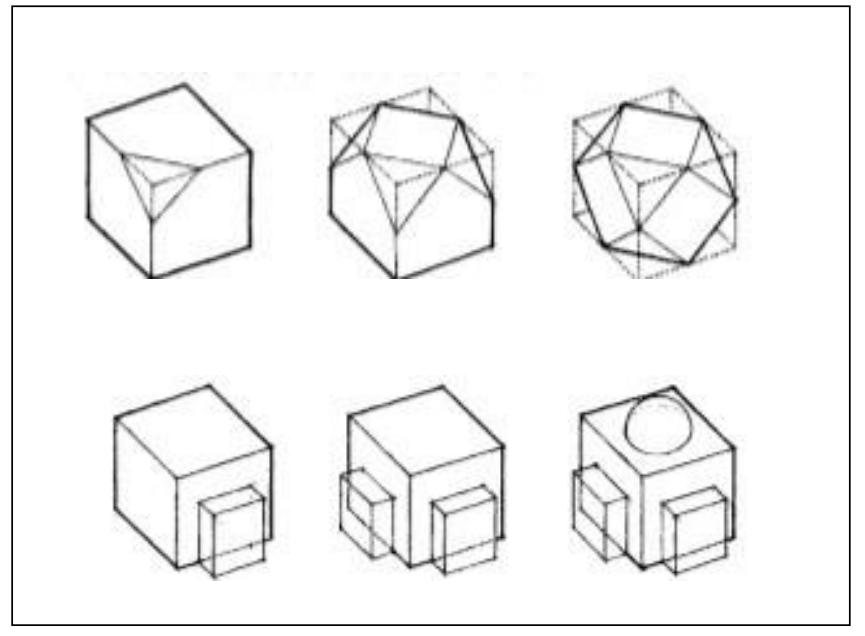

Figure 1. Addition and Subtraction Mass Forming (Source: Ching, F. D.,2014)

One factor that needs to be considered while creating the concept of the outdoor space is the circulation in the site. Poor circulation could cause traffic jams inside even outside the site. Pulling in the entrance of the site can prevent traffic jam around the site from happening because this action gives space for the vehicles which need to enter the site space to queue [7].

A design that gives special attention to the needs of the senior citizens and the disabled must always be present whenever it is possible [8]. Universal outdoor space has become a standard for public buildings, and one of the ways to achieve this is by providing a ramp to accommodate their circulation needs.

The design of the dance academy needs two different structures. The campus building, which has a four-floor height, is categorized as a middle rise structure and will be using the rigid frame structure (Figure 2). While the auditorium is a long span building, it needs a different structure. The truss frame is one of them.

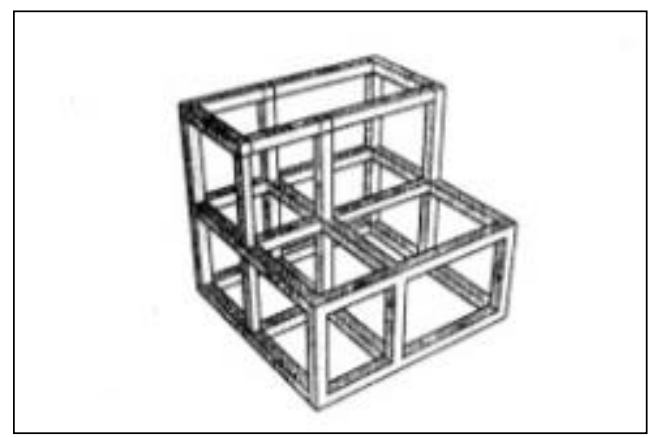

Figure 2. Rigid Frame for Story Building Structure

(Source: Idham, N. C.,2012) 
Water utility for story buildings needs to use the upper tank system (Figure 3), which uses the gravitation force to distribute the water to all floors and rooms. In a story building project, to create efficiency in the piping cost, the toilets are usually stomped together in one area [9].

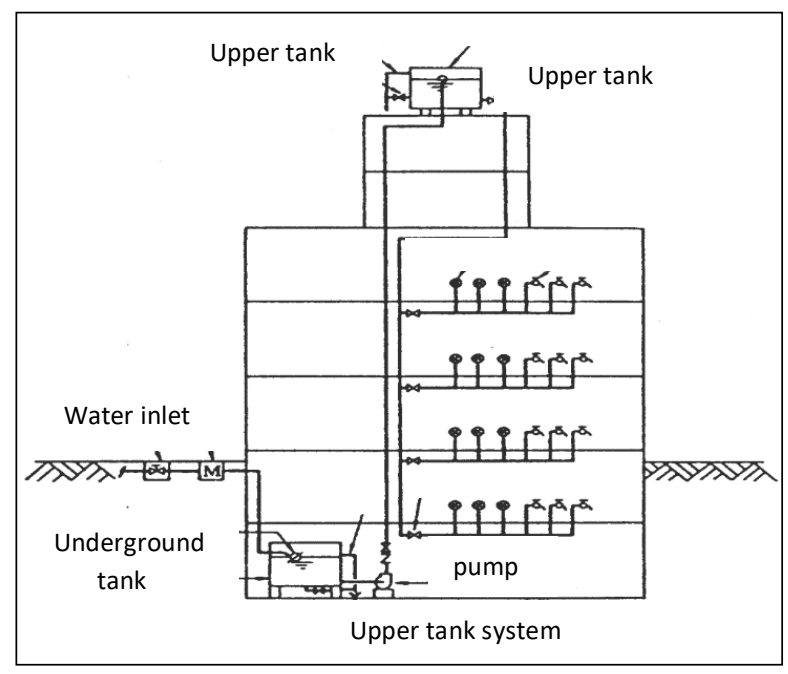

Figure 3. Feed Up Water Distribution System

(Source: Juwana, J. S.,2005).

The ideal temperature that a human body needs to be able to do well in their activities is called comfortable optimal temperature $\left(22,8^{\circ} \mathrm{C}-25,8^{\circ} \mathrm{C}\right.$ with $70 \%$ humidity). These numbers are below the air condition in Indonesia, which reaches $35^{\circ} \mathrm{C}$ with $80 \%$ humidity [10]. Thus a mean is needed to adjust the temperature inside the building using air conditioners.

\section{Methodology}

In the process of designing the Dance Academy, data are needed. The data that are needed can be classified into two categories. Primary data are data that are gathered directly about the site location, the existing environment, site borders, views, climate condition, existing utility, etc. while secondary data consists of data that can be obtained through literature review about the use of metaphor in architecture, local dance art, characteristic and also standards for academic-type buildings. These data are needed to create an ideal design for the dance academy. The data that have been obtained was then analyzed. From the analyzed data, the idea of the metaphor and visual were then transferred into the standards of the academic building to form a design that provides value, effectivity, and efficiency.

The process of choosing the site start by finding the Indonesian government regulation for high education building and following the Medan government urban development plan. After finding numerous sites that meet the regulation, the data between the sites are compared to see which one can provide the best output to the design. 


\section{Result and Discussion}

The use of Metaphor

To achieve the balance between body and soul in architecture, the bond between the facility and the people using it needs to be created. Thus to create the bond between the dance academy and the dancers using the building, a metaphor of a dance choreography is used. The basic concept of the metaphor that is used in the dance academy is like that of a history storytelling. The metaphors start like the history of dance art. The first dance art that was developing in Indonesia was a traditional dance, which was an original dance art from Indonesia. Then when western culture starts to spread in the country, people start to know the classical dance. "Tari Makan Sirih" as the representation of the Indonesian traditional dance art and Ballet dance as the representation of the classical dance is chosen to be the basic concept of the metaphors that are going to be used.

Room and Space Requirement

By using the data of the activity flow and reference from books, the room and space that a dance academy require is (Table 1 ).

Table 1. Room requirement for Dance Academy

\begin{tabular}{|c|c|c|c|c|c|}
\hline Room & Capacity & Quantity & $\begin{array}{l}\text { Room } \\
\text { Standards }\end{array}$ & $\begin{array}{l}\text { Sou } \\
\text { rce }\end{array}$ & Total \\
\hline \multicolumn{6}{|l|}{ Academic Space } \\
\hline Big Studio & 30 people & 3 & $255 \mathrm{~m} 2$ & $\mathrm{Ne}$ & $765 \mathrm{~m} 2$ \\
\hline Small Studio & 12 people & 3 & $81 \mathrm{~m} 2$ & $\mathrm{Ne}$ & $243 \mathrm{~m} 2$ \\
\hline Classroom & 50 people & 3 & $2 \mathrm{~m} 2 / \mathrm{man}$ & $\mathrm{Ne}$ & $300 \mathrm{~m} 2$ \\
\hline gym & 50 people & 1 & $200 \mathrm{~m} 2$ & $\mathrm{Ne}$ & $200 \mathrm{~m} 2$ \\
\hline Auditorium & $\begin{array}{l}500 \text { people } \\
+20 \text { dancers }\end{array}$ & 1 & $\begin{array}{l}2 \mathrm{~m} 2 / \text { audience } \\
+3 \mathrm{~m} 2 / \text { dancers }\end{array}$ & $\mathrm{Ne}$ & $1060 \mathrm{~m} 2$ \\
\hline Library & - & 1 & $200 \mathrm{~m} 2$ & Gov & $200 \mathrm{~m} 2$ \\
\hline Field & - & 1 & $427.5 \mathrm{~m} 2$ & As & $427.5 \mathrm{~m} 2$ \\
\hline Total area & & & & & $3195.5 \mathrm{~m} 2$ \\
\hline Circulation $20 \%$ & & & & & $639.1 \mathrm{~m} 2$ \\
\hline Total Area + Circulation & & & & & $3834.6 \mathrm{~m} 2$ \\
\hline \multicolumn{6}{|l|}{ Public Space } \\
\hline Car park & 200 unit & 1 & $16.8 \mathrm{~m} 2$ & $\mathrm{Ne}$ & $3360 \mathrm{~m} 2$ \\
\hline Motorcycle park & 80 unit & 1 & $2 \mathrm{~m} 2$ & $\mathrm{Ne}$ & $160 \mathrm{~m} 2$ \\
\hline Lobby & 30 people & 1 & $3 \mathrm{~m} 2 / \operatorname{man}$ & As & $90 \mathrm{~m} 2$ \\
\hline Student lounge & 20 people & 1 & $2 \mathrm{~m} 2 / \mathrm{man}$ & As & $40 \mathrm{~m} 2$ \\
\hline Toilet & Four people & 4 & $2 \mathrm{~m} 2 / \operatorname{man}$ & As & $16 \mathrm{~m} 2$ \\
\hline Canteen & 100 people & 1 & $4 \mathrm{~m} 2 / \mathrm{man}$ & As & $400 \mathrm{~m} 2$ \\
\hline Osteotheraphy room & Five people & 1 & $2 \mathrm{~m} 2 / \mathrm{man}$ & As & $10 \mathrm{~m} 2$ \\
\hline
\end{tabular}




\begin{tabular}{|c|c|c|c|c|c|}
\hline Total area & & & & & $4076 \mathrm{~m} 2$ \\
\hline Circulation 20\% & & & & & $815.2 \mathrm{~m} 2$ \\
\hline Total Area + Circulation & & & & & $4891.2 \mathrm{~m} 2$ \\
\hline \multicolumn{6}{|l|}{ Administrator Space } \\
\hline Director room & One people & 1 & $4 \mathrm{~m} 2 / \operatorname{man}$ & Gov & $4 \mathrm{~m} 2$ \\
\hline $\begin{array}{ll}\text { Head and } & \text { Secretary } \\
\text { department room } & \end{array}$ & Two people & 3 & $4 \mathrm{~m} 2 / \operatorname{man}$ & Gov & $24 \mathrm{~m} 2$ \\
\hline Teaching Staffroom & 23 people & 1 & $4 \mathrm{~m} 2 / \operatorname{man}$ & Gov & $92 \mathrm{~m} 2$ \\
\hline Administration service room & 12 people & 1 & $4 \mathrm{~m} 2 / \operatorname{man}$ & Gov & $48 \mathrm{~m} 2$ \\
\hline Meeting room & 20 people & 1 & $2 \mathrm{~m} 2 / \operatorname{man}$ & Gov & $40 \mathrm{~m} 2$ \\
\hline Total area & & & & & $208 m 2$ \\
\hline Circulation $20 \%$ & & & & & $41.6 \mathrm{~m} 2$ \\
\hline Total Area + Circulation & & & & & $249.6 \mathrm{~m} 2$ \\
\hline \multicolumn{6}{|l|}{ Utility space } \\
\hline Generator room & $\begin{array}{l}\text { One } \\
\text { generator }\end{array}$ & 1 & $30 \mathrm{~m} 2 /$ machine & As & $30 \mathrm{~m} 2$ \\
\hline Control panel room & 1 & 1 & $16 \mathrm{~m} 2$ & As & $16 \mathrm{~m} 2$ \\
\hline Waste room & One truck & 1 & $20 \mathrm{~m} 2$ & As & $20 \mathrm{~m} 2$ \\
\hline Water pump room & One pump & 1 & $20 \mathrm{~m} 2 /$ pump & As & $20 \mathrm{~m} 2$ \\
\hline Jockey pump room & One pump & 1 & $30 \mathrm{~m} 2 /$ pump & As & $30 \mathrm{~m} 2$ \\
\hline Control audio room & $\begin{array}{l}\text { Three } \\
\text { people }\end{array}$ & 1 & $5 \mathrm{~m} 2 / \mathrm{man}$ & As & $15 \mathrm{~m} 2$ \\
\hline Total area & & & & & $131 \mathrm{~m} 2$ \\
\hline Circulation $20 \%$ & & & & & $26.2 \mathrm{~m} 2$ \\
\hline Total Area + Circulation & & & & & $157.2 \mathrm{~m} 2$ \\
\hline Total Area Needed & & & & & $9132.6 \mathrm{~m} 2$ \\
\hline
\end{tabular}

$\begin{array}{ll}\mathrm{Ne} & =\text { Neufert Architect Data } \\ \mathrm{Gov} & =\text { Government Standards } \\ \text { As } & =\text { Assumption }\end{array}$

\section{Mass Forming}

The mass of dance academy is divided into two due to the needs of using different structures between the auditorium building, which uses a long-span structure and the campus building, which use a rigid frame structure. The process of mass forming is also taking the metaphor of dance history. The first dance art known by the local Indonesian is a traditional dance. The auditorium building, which is categorized as a public space, will be taking the front spot and will also act as a welcoming gate for those who enter the site. The quality and the function of the auditorium building are then metaphor to match the similarity in "Tari Makan Sirih" (Figure 4), which is a welcoming traditional dance from the local Malay race. 


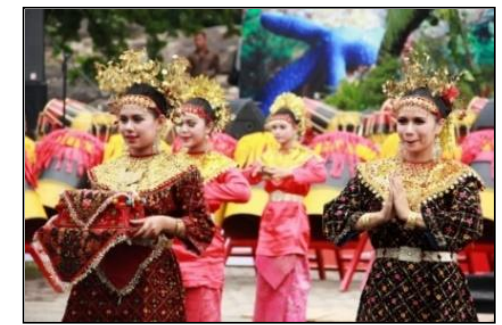

Figure 4. "Makan Sirih" Dance for Metaphor Concept source: https://www.indonesiakaya.com accessed 9/2018

The auditorium building is given a tunnel shape lattice (Figure 5), which is the metaphor of the dancer's hands that are welcoming guests into the site. The front façade of the building uses the metaphor of the dancer's head decoration. The trapezium-shaped canopy is taken from the "sirih" box, which the dancers hold while they are dancing.

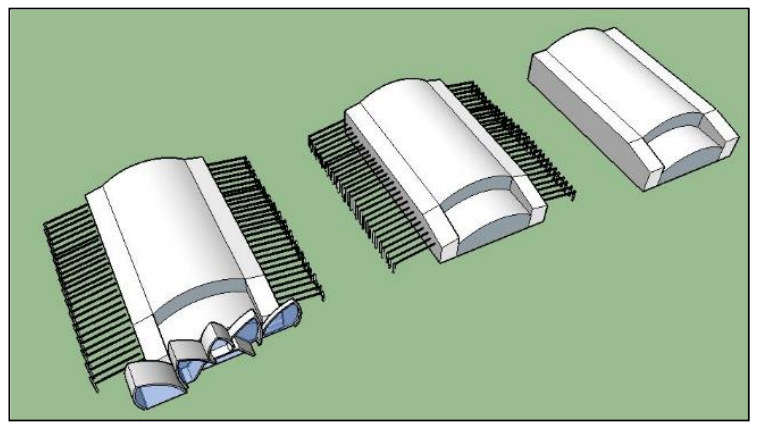

Figure 5. Auditorium mass forming process

The campus building uses the metaphor of a ballet dancer (Figure 6), which is a sign that colonial age and its culture have started developing in Indonesia. The campus building uses a radial structure that is taken from using the metaphor on the spinning ballet dancer. There are expansion masses added to the main mass, symbolizing the right hand that is spinning and the left hand that is raised vertically (Figure 7). After that, the lattice façade was added to the expanding mass to emphasized the movement of the hand. This lattice was later used as the theme style in the design that unifies the auditorium mass and the campus mass (Figures 8 and 9).

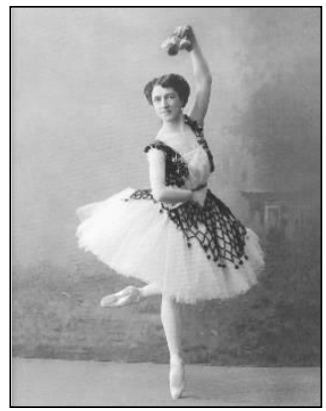

Figure 6. Ballet Dance for Metaphor Concept source: https://en.wikipedia.org accessed 9/2018 


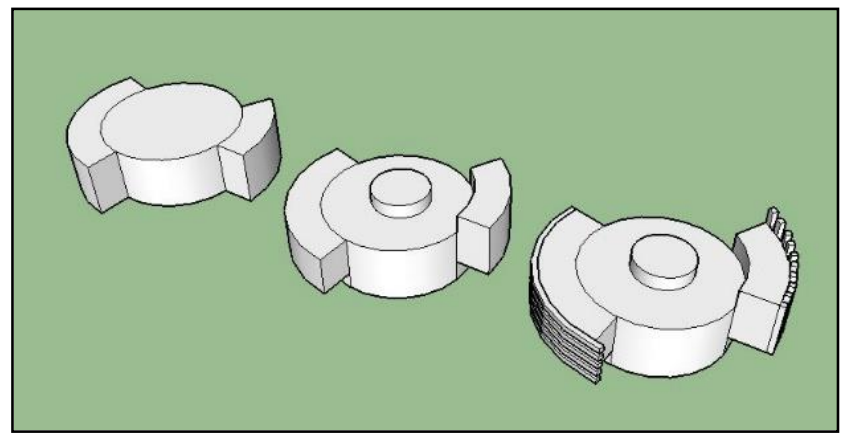

Figure 7. Campus mass forming process

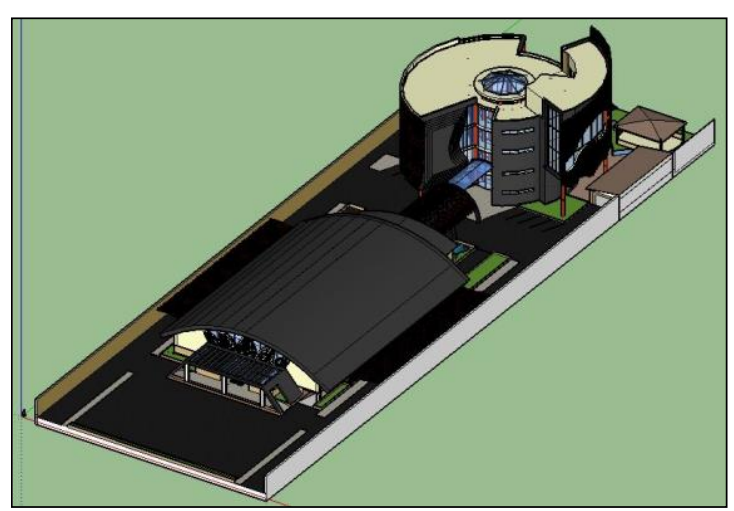

Figure 8. Final Project Model

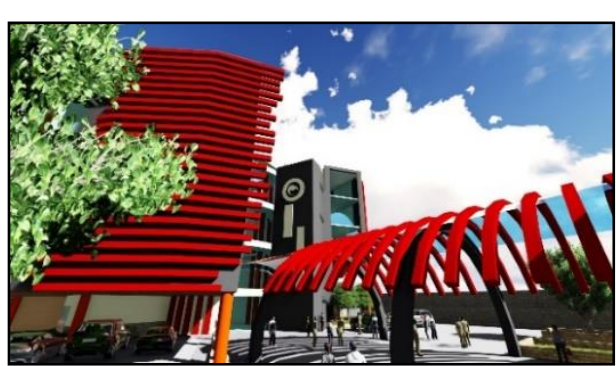

A

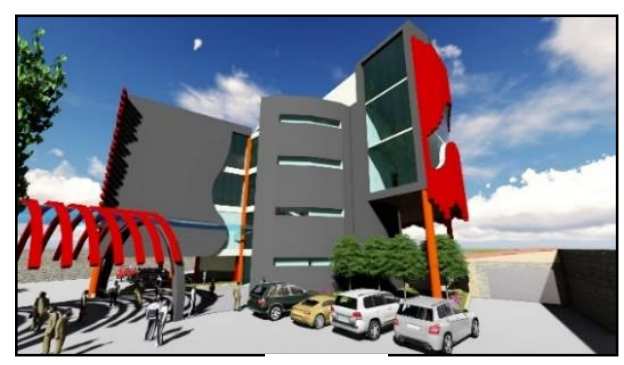

B

Figure 9. Campus Exterior Building (A) right view (B) left view

Circulation and Outdoor Space

Utilizing the long site size, it is possible to pull in the entrance further into the site creating a queueing space for vehicles (Figure 10). 


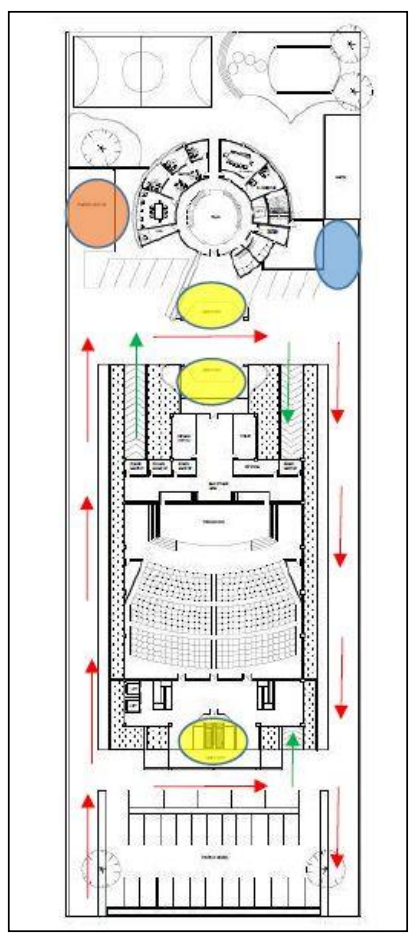

Figure 10. Circulation for Vehicle in Site

Outdoor space was designed using the metaphor of the welcoming guest value from the "Makan Sirih" dance. The auditorium building is used as a gateway to access deeper into the site. These accesses are given lattice, which is the metaphor of the elegant dancers' hand. This lattice also gives a series of experiences to those who pass through it (Figure 11).

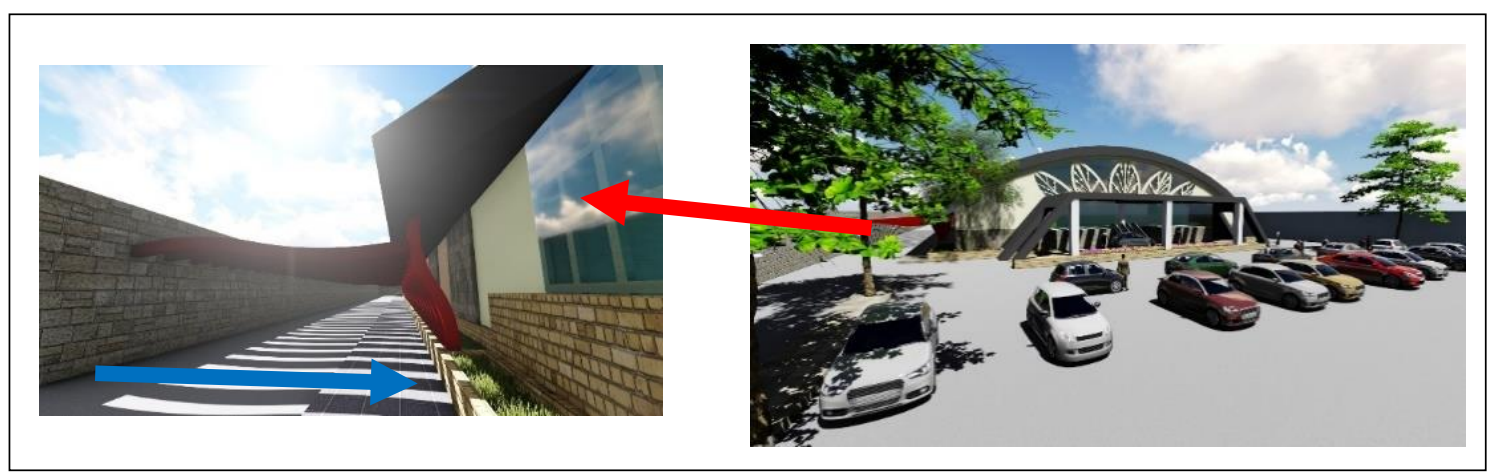

Figure 11. Steel Lattice Gateway concept

Interior

The auditorium ceiling was designed with a drop panel that follows the pattern of the "sirih" leaf (Figure 12). This amplifies the value of the metaphor that is used in the auditorium building. The auditorium building now holds the value as the "sirih" box that is served to the guest, just like how the auditorium serves the dance art to the audience. 


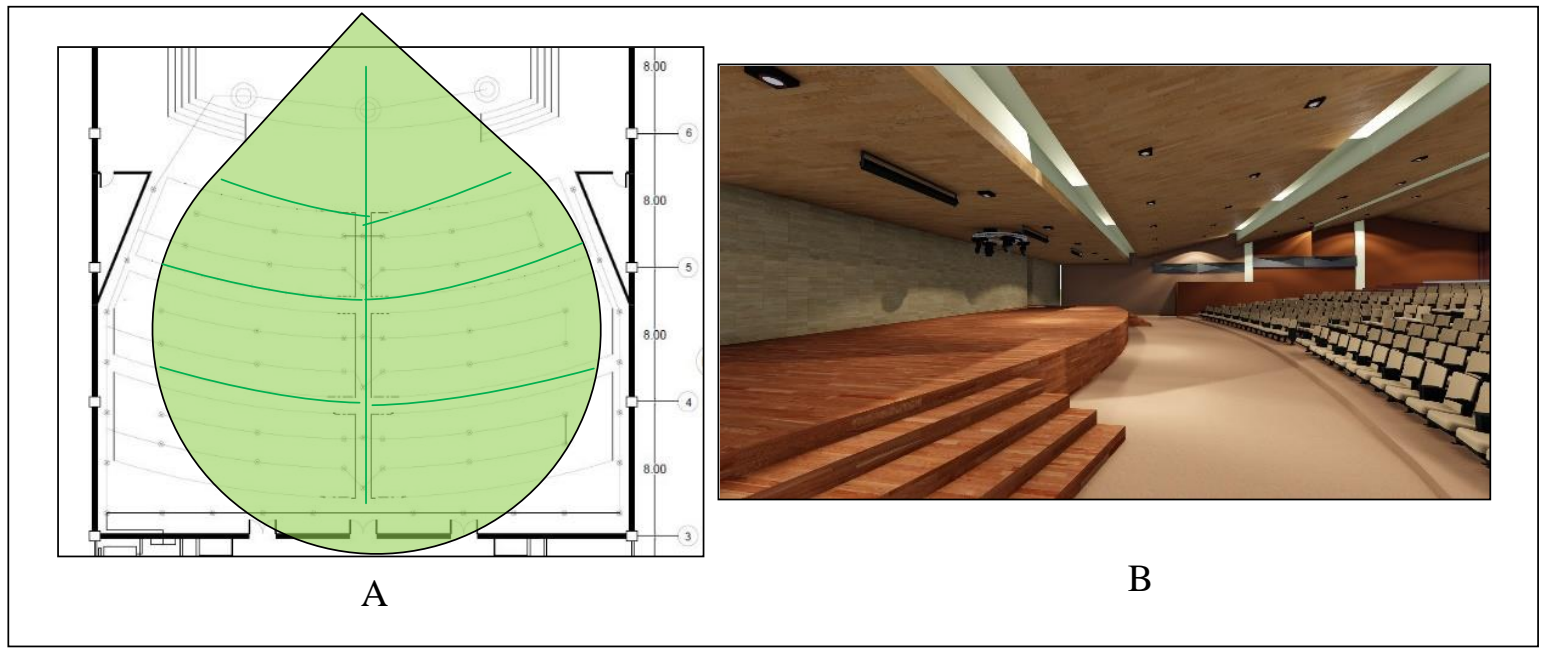

Figure 12. Auditorium's interior (A) Plafond plan (B) Indoor Space

Utility

To ensure the water is distributed to all areas, the campus building uses the feed up system (Figure 13) while the auditorium uses the ground tank pump system (Figure 14).

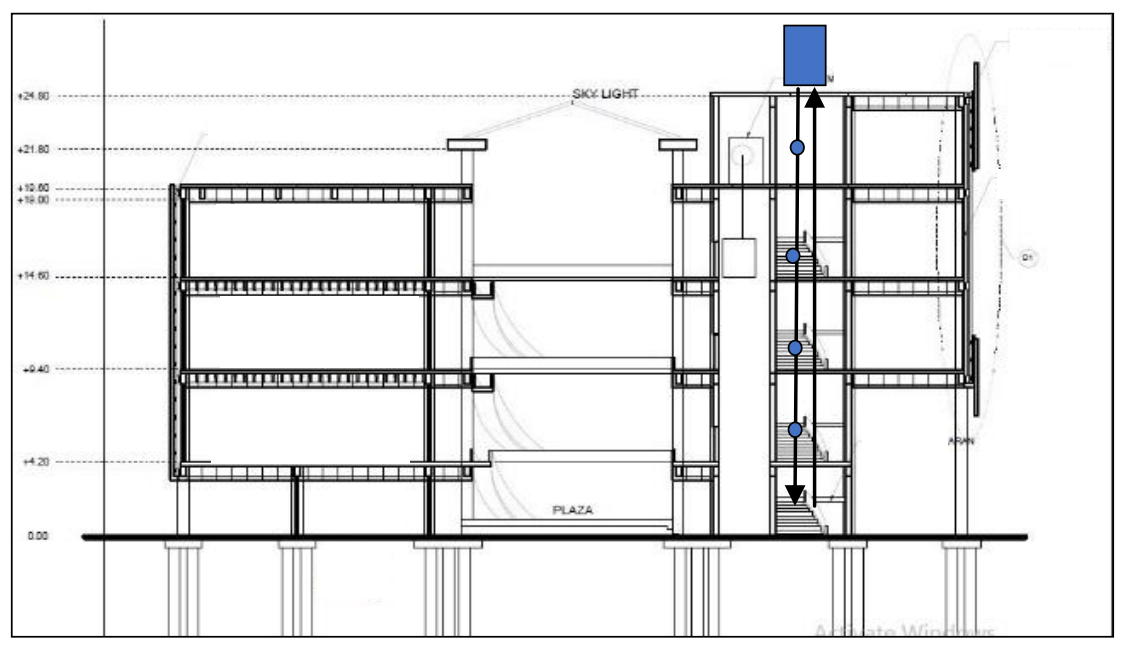

Figure 13. Campus Water Distribution

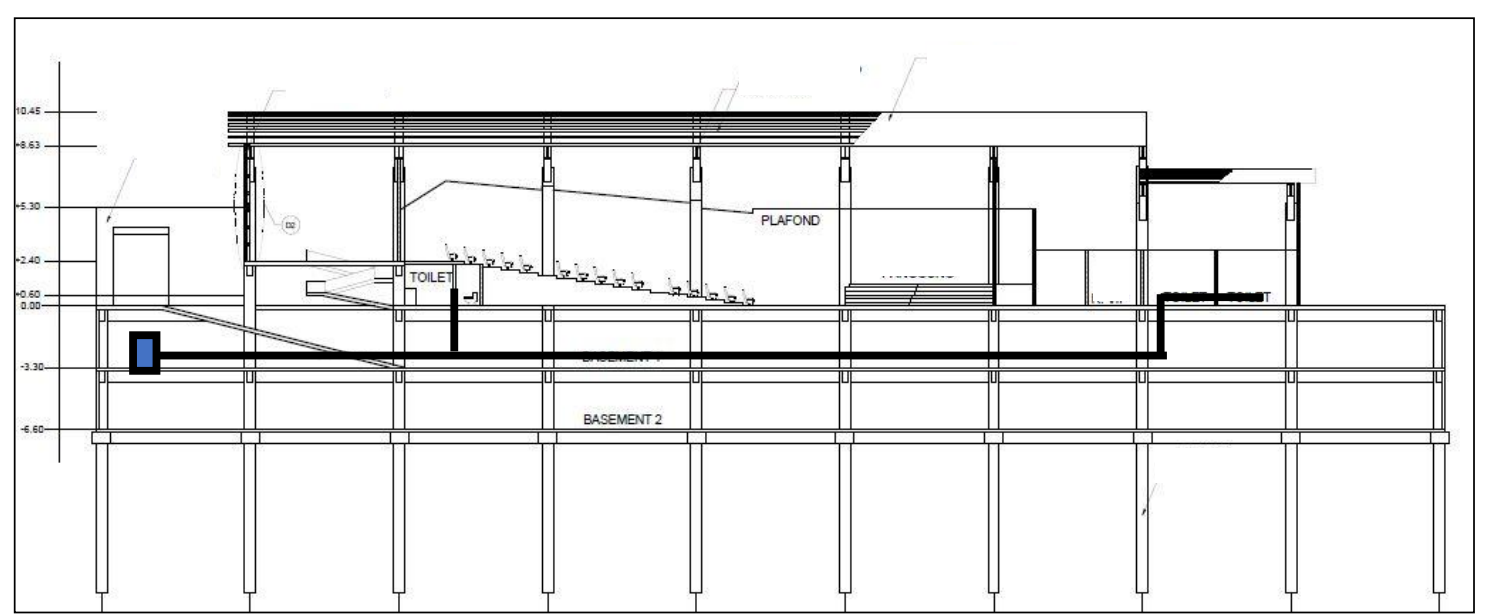

Figure 14. Auditorium Water Distribution 
The Auditorium uses the central AC system (Figure 15) because once the building is needed the whole building needs air cooling while the campus building uses the VRF AC system (Figure 16) since not all room needs to be cooled at the same time.

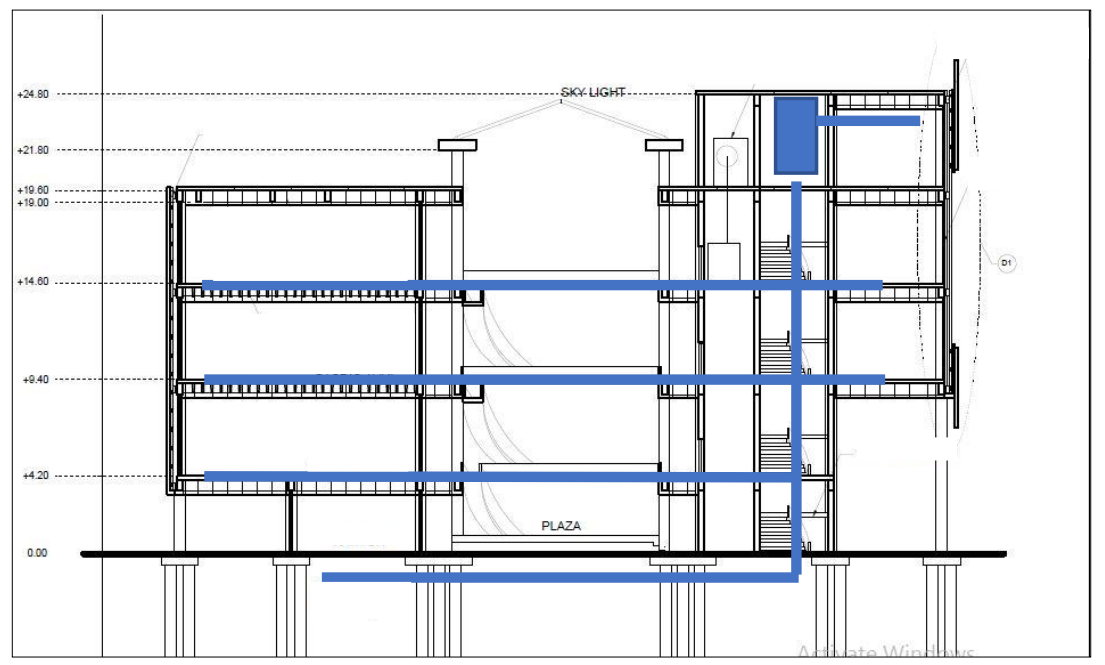

Figure 15. Central AC system for Auditorium Source: https://cvastro.com accessed 9/2018

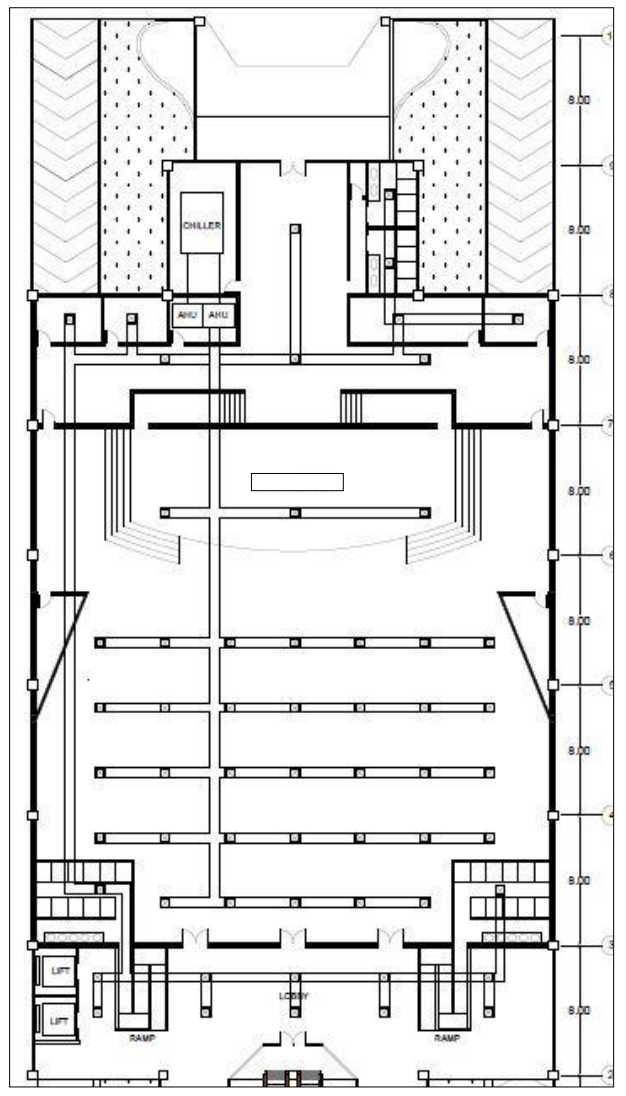

Figure 16. VRF AC system for Campus

Source: https://coolautomation.com accessed 9/2018 


\section{Conclusion}

The use of Metaphor in designing dance academy can create a bond between the academy as the facility of dance art and the art of dance, which can provide the pride and other advantages to the dancers. The use of metaphor is emphasized in the building visualization, which can be seen clearly through the mass forming and the façade of the building.

\section{Acknowledgment}

This article is written by researchers who are partly funded by Universitas Sumatra Utara and was given out as a donation to the government to preserve and improve the value of design, local wisdom, arts, and ethnic.

\section{References}

[1] K. Karatani, Architecture as Metaphors, Columbia: MIT Press, 1995.

[2] T. R. K. B. Indonesia, Kamus Bahasa Indonesia, Jakarta: Pusat Bahasa Departemen Pendidikan Nasional, 2008.

[3] H. Casakin, "Assessing the Use of Metaphors in the Design Process," Environment and Planning B, pp. 253-268, 2006.

[4] A. C. Antoniandes, Poetics of Architecture, Van Nostrand Reinhold, 1990.

[5] E. Neufert and P. Neufert, Architects' data, John Wiley \& Sons, 2012.

[6] F. D. Ching, Architecture: Form, space, and order, John Wiley \& Sons, 2014.

[7] E. H. Susanto, "Gelanggang Tenis dan Squash di Kabupaten Kubu Raya," Jurnal Online Mahasiswa S1 Arsitektur UNTAN, vol. 3, no. 2.

[8] C. C. Marcus and F. Carolyn, People places: design guidelines for urban open space, John Wiley \& Sons, 1997.

[9] H. Poerbo, Utilitas Bangunan, Jakarta: Penerbit Djambatan, 1992.

[10] B. Talarosha, "Menciptakan kenyamanan thermal dalam Bangunan," Jurnal Sistem Teknik Industri, vol. 6, no. 3, 2005. 